\title{
New Configuration of the Brazilian State: Liberty and Development in the Evolution of Government in Brazil
}

\author{
Maya R eyes-Ricon * \\ E-mail address: mayareyes@yahoo.com \\ Escola B rasileira de A dministração Pública e de Empresas/Fundação Getúlio V argas - EBA PE/FGV \\ Rio de J aneiro, RJ , B razil.

\section{Deborah M oraes Zouain} \\ E-mail address: deborah.zouain@fgv.br \\ Escola B rasileira de A dministração Pública e de E mpresas/Fundação Getúlio V argas - EB A PE/FGV \\ Rio de J aneiro, RJ , B razil.
}

\section{R oberto da Costa Pimenta}

E-mail address: roberto.pimenta@fgv.br

Escola B rasileira de A dministração Pública e de Empresas/Fundação Getúlio V argas - EBAPE/FGV

Rio de Janeiro, RJ , B razil.

\section{Gustavo de O liveira Almeida}

E-mail address: goalmeida@gmail.com

Escola B rasileira de A dministração Pública e de Empresas/Fundação Getúlio V argas - EBAPE/FGV

Rio de J aneiro, RJ , B razil.

\begin{abstract}
The recent events in the global economy have revitalized the debate about the size and functions of the State. The neoliberal discourse was put in check, reopening the discussions concerning Market Liberty and the importance of the State. Since the proclamation of the Republic, the Brazilian government has undergone numerous reforms, sometimes assuming a liberal, external market dependent orientation, while at other times assuming an authoritarian, developmental state-driven orientation. The aim of this article is to develop insights into the evolution of the governmental organization and reflect on the assumptions that lie behind the various reforms that have taken place since the beginning of the Republic. The theoretical framework is divided into three parts: D evelopment and Liberty based on the perspectives of Friedrich Hayek and A martya Sen; the role of the State and its impact on the economy and; the formats assumed by the B razilian State throughout the history of the Republic. The latter part of the work returns to the theoretical framework, summarizing all that has been discussed in order to fulfil the aims of the study.
\end{abstract}

Key words: governmental organization; size of the state; reform of the state,

Received 15 J anuary 2010; received in revised form 17 A ugust 2010.

Copyright (C) 2010 Brazilian Administration Review. All rights reserved, including rights for translation. Parts of this work may be quoted without prior knowledge on the condition that the source is identified.

\footnotetext{
* Corresponding author: M aya Reyes-Ricon

EBA PE/F GV, Praia de Botafogo, 190 5th floor, B otafogo, Rio de Janeiro, RJ, 22250-900, B razil.
} 


\section{INTRODUCTION}

It is curious that a discussion that might appear to be restricted to the past, in light of the recent hegemony of neoliberal rhetoric which defends a global market economy, supported by the free circulation of financial capital, could have reemerged on the world stage with so much emphasis (Bresser-Pereira, 2009; Datz, 2009; Santos et al., 2007; Sheppard \& Leitner, 2010). The origin of the crash of the U nited States financial system in 2008 lay in the unsustainable and irresponsible credit offer by financial institutions based on the property market's assets, whose instability not only challenged the solidity of banks and financial and insurance companies, but also the liberal vision of a self-regulated market (B resser-Pereira, 2009), returning once again to the discussion concerning to what extent the State plays an active and important role in the regulation, and principally in the stimulation, of the economy (Datz, 2009; Gore, 2000). This shift of ideas could also be detected during the 1997 Asian crisis, when Keynesian economists and ideas were once again in vogue, as seems to be the case whenever a crisis hits the economy. To quote Datz (2009, p. 620) "K eynes is back in fashion".

This new cycle, which began after real estate crisis was identified as an important shift from the Washington Consensus, was first presented in the works of J ohn Williamson $(1990,1993,1997)$, who coined the term, and also set out a specific formulation of the approach in the late 1980s. A widespread adoption of this approach then followed in developing countries and was sponsored by agencies such as the International Monetary Fund and World Bank, and the policies were known as stabilization and structural adjustment policies (Gore, 2000).

The measures proposed were "10 policy measures about whose proper deployment Washington can muster a reasonable degree of consensus" (Williamson, 1990, p. 7). These were related to the principles that governments should reform their policies in order to achieve macroeconomic stability, controlling inflation and reducing fiscal debts, i.e., spending less, with a complete opening of the economy to the world, coupled with the liberalization of capital flow (FDI), deregulation of the economy, leaving the production and creation of services as a duty of the market, according to the idea that that the market would be more efficient and better for the economy (Cerny, 2008; Gore, 2000; W illiamson,1997).

Therefore, with policies such as trade liberalization, Latin A merican and Eastern European leaders to a large extent followed the path of privatization, fiscal austerity and financial deregulation in the 1990s (Cerny, 2008; Datz, 2009). B razil adopted some of the measures proposed, beginning in the 1990s, and for the whole decade the country's policy adhered to the so-called Washington Consensus. For instance, in 1989 the average import tariff was 41\%. When President Collor was sworn in the following year, the tariff began a continuous decline, dropping to 13.5\% in 2002 (A mann $\&$ Baer, 2008).

Throughout the 20th century, the Brazilian State underwent many changes and reforms, alternating between liberalization and periods of intense state intervention in economic activities (A mann $\&$ Baer, 2008). From the construction and affirmation of the republican state, tailored to serve the political and economic oligarchies during the so called Old Republic and the germination of the intervening nationalist New State of Getúlio V argas, or from that to the developmentalist State of the 50s and 60s, and the authoritarian period of the military dictatorship until the contemporary regulatory state, established with re-democratization and through extensive and profound reforms, that many label as having neo-liberal orientation, the trajectory and the organizational changes of the Brazilian State have reflected the ideological and political world changes in a very expressive way (Peixoto, 2008; Selcher, 1990; Souza, 1992).

The objective of this article is to provide insights into the evolution of the Brazilian governmental organization and to reflect on the assumptions that lie behind the diverse reforms that took place after the proclamation of the Republic, taking into account the dimensions of development and liberty as they relate to the State/M arket dichotomy. To achieve this goal, the theoretical framework is divided into three parts: first, it discusses the relationship between development and liberty, based on Friedrich Hayek's and A martya Sen's perspectives, both Nobel laureates, having been awarded the Prize of 
Economic Sciences, and how these key-concepts relate to the interaction between the market and the State. This is followed by a discussion about the State's role and its performance in the economy. The third part presents an analysis of the forms that the Brazilian State has assumed in its trajectory since the beginning of the Republic. In the final considerations, the last part of the work returns to the theoretical framework, summarizing everything that has been discussed in order to fulfill the objective of the study.

\section{STATE, DEVELOPMENT AND LIBERTY}

In the first two chapters of "Law, L egislation and Liberty", Hayek (1973, pp. 8-54) argues that there are two conflicting ways of viewing the standards of human activities or society itself. The first, which he criticizes, is based on the idea of a constructivist rationalism, which is derived from the thoughts of Descartes. What Hayek denies is the vision that human institutions are only going to serve human purposes if they are specifically created for such a purpose. This is how he questions the concept of "social contract", as defined by Hobbes and Rousseau. For Hayek, what exists, de facto, is not the projected institutions, but rather the result of customs, habits and practices, which were created from the interaction of different individuals in society. We guide ourselves according to rules whose origins we do not know, rules that have evolved through a socially oriented selection to what they are at a given moment in time (Hayek, 1973).

The center of his criticism of a Cartesianly conceived social order lies in the limitation of human rationality when faced with the complexity of social reality. A complete rationality (in a Cartesian sense) is dependent on equally complete knowledge about all of the prominent facts. The corollary is the identification of the constructivists' characteristic error, which Hayek calls "the synoptic illusion", in other words, the illusion that everything that is meant to be known, is known. He sees this idea of a society that is deliberately planned as somewhat naive (Hayek, 1973).

Although some academics seemed to interpret this affirmation as an apology against planning, Colander (2005) clarifies the issue stating that Hayek's intention was a call for an understanding of the limitations of any planning by considering the complexities of a society, even though the planning must be done. However, total knowledge or accuracy is either not attainable or the understanding or knowledge of all the facts is incomplete.

A nother point of vital importance for Hayek is evolution. A lthough the author alleges that this concept bel ongs to other areas of knowledge, he cannot break ties with biology, stating that the social Darwinists' mistake lay in the belief that what was selected was the individual, while, in reality, it was the successful behaviors.

Based on these two thoughts, Hayek talks about perception and obedience to the rules of conduct, which shape the individual through culture; in other words, through immersion in society. Regarding the positivist Cartesian law, the author opposes the natural law that drifts from human action and not from deliberation. It is a law or observed rules that stem from evolution, being the product of a spontaneous order (Hayek, 1973).

In his line of argument, this spontaneous order - Cosmos - unlike a deliberate order - Taxis - is more complex by nature and evolves from the multiplicity of elements. A dditionally, it will always stem from the adaptation of a great number of particular facts, which will be unknown in their totality to all (Hayek, 1973).

It is exactly due to this complexity and character of adaptation of each element to the other that the power of control on order remains diminished in relation to the constructed order, also known as taxis (Hayek, 1973). 
A deliberate order is certainly deliberated by a person or a group of people who constitute an elite with great power over this taxis; an elite that is incapable of knowing all the minor details related to the social reality, and whose central interest is, naturally, their own. This taxis, which originates from a limited rationality, can only be imperfect and, in its imperfection and vulnerability to despotic control, it is a fragile order with low complexity (Hayek, 1973).

A spontaneous social order stems from the free action of all el ements - the individuals that constitute it. It is from the liberty of existence and from the adaptation of others to this liberty that cosmos arise. This social interaction, guided by individual pressure to reach one's own self interest is only limited by rules of behavior that evolve from this same dynamic and result in a self generated order. This way, we not only come across the potential of a society that can construct itself from individual interests, but which also self-develops; in other words, it is capable of evolving to ranks of higher complexity, taking increasingly more elements into account.

In "Heirs to Darwin", Marcel Blanc (1994, p. 184) presents us with the impact of the evolutionist thought that was born with the theory of the evolution of species and has had a great impact on social sciences. The first thinkers to cross this frontier between biological and social evolution were al so part of Darwin's intellectual circle, including his cousin Francis Galton. One of his worries was the regression that the human race would be suffering due to the elimination of competition and selection, which took place because of assistance for the sick and poor who, according to nature's law, should perish for being less apt. This doctrine, which could be considered the seed of eugenic thinking, developed from the end of the 19th century until the mid 20th century, when it reached its apex as the ideas that lay behind the Third Reich.

As Hayek himself argued, the mistake of social Darwinists was to think about the selection of individuals rather than behaviors. In this way, Hayek's evolutionary thought was closer to a 'social L amarckism', since social evolution is much more similar to the theory of inherited traits, as mentioned by Lamarck.

Based on these observations, it can be argued that underneath Hayek's libertarian speech there is a social order of domination. The total liberty that the logic of a free market (and Hayek himself) preaches is nothing more than the logic of predominance of the strongest over the weakest.

The same theme - liberty and development - is approached by A martya Sen (2001, pp. 135-171) in "Development as Liberty". His basic argument acknowledges the need for a critical examination of views on the political and economic role of the market. He also proposes the search for a middle ground between the market's defense and criticism.

To this author, the idea of the market is more important than the results it generates because it is connected to the concept of liberty; this liberty needs to be contemplated in various dimensions, especially in a world where the deprivation of employment liberty - a fundamental deprivation - has become a critical question, even if it is seen from different angles by different countries. For the author, the fall of the socialist regimes could be explained not only through the economic inefficiency of communism, but also in terms of the denial of basic liberties through the exclusion of market mechanisms (Sen, 2001).

Female labor, like child labor, is discussed from the starting point of arbitrariness. In the case of child labor, children are deprived of the liberty to attend school, either due to social-economic reasons or the precariousness of the educational system. Perverse is the adjective used by Sen to describe the vicious circle that lies in the economic construction of the appointing of laboring children. Now, in relation to women, the denial of the right to work outside the household is a violation of women's liberty and, also, it is a way of restricting their gain of economic power and women's independence. In this case, the mechanics of deprivation of liberty can either be explicit or more subtle, perpetuated by traditional values or lack of support or company and government structure. Either way, it addresses the need for open discussion concerning social problems and the advantage of social associations as an element of social change (Sen, 2001). 
Sen argues that the liberty of transaction, inherent to the market, is critical, regardless of the mechanisms and achievements that may or may not come with it. However, the market is imperfect. The merit of market mechanisms is obtaining economic efficiency or a "Pareto Optimality" (Sen, 2001, p. 141) - which is the equilibrium in the utilities acquired by those involved in the exchange. A ccording to A rrow-Debreu's theorem, it is not possible to increase everybody's utilities at the same time (Sen, 2001). W ith some linguistic agility, Sen transforms economic utility into individual liberties and resolves the paradox of development, proposing that, in a competitive market equilibrium, no one may have an increase in liberty without there being a decrease in another individual's liberties. One's liberty ends where another's begins is what he seems to be telling us.

$\mathrm{H}$ is argument accentuates the fact that the liberty of choice depends fundamentally on the opportunity to make good choices, choices that are real and quality-based to the individual. He also argues that true inequality lies in the restriction of access to quality in real opportunities of choice, which, in turn, would mean a restriction to substantive liberties and individual capability (Sen, 2001).

In this scenario, the government's role emerges with great importance in the creation and maintenance of the equilibrium between efficiency and equity through regulation, preventing the creation of monopolies and privileges and also by providing services such as public education. However, in order for that to happen, it is crucial to maintain political liberties due to the fact that liberty of association and democratic action acts as an auxiliary force when it comes to obtaining other liberties (Sen, 2001).

For Sen, reflection concerning the market must be made in a multidimensional way that combines "the extensive use of markets with the devel opment of a broader approach that also emphasizes other types of liberty (democratic rights, guarantees of security, opportunities for cooperation, etc)" (Sen, 2001, p. 152), which leads us to the conclusion that if institutions contribute to our liberties, their role and actions should be analyzed in the light of their contributions to those same liberties. In other words, we should ponder development from the perspective(s) of liberty (ies).

As a corollary, we see that Sen (2001) plunges deep when he talks about the need and the kind of liberty that is necessary so that the spontaneous order Hayek associates with market can, in fact, exist. $M$ ore precisely, political liberty is a way of allowing the market to function with equity and as an adequate supplement so that, in fact, the majority of interests can participate in this readjustment, to which other interests will also have to re-adapt.

Thus, the presence of the State as the organizer and provider of resources, be they material (subsidized raw material, land) or social (education, health, etc), is fundamental to the market's health (Rodrigues, 1990), taking society to an even higher complexity, in which more actors are contemplated and, as a consequence, generating greater development. Through Sen's proposals, we can also think of the State and the $M$ arket as dynamics of pressure and adaptation. In that sense, the State is just another element included in the spontaneous social order, even more so if we assume the democratic State as a model, since it assumes the consensus of various voices.

By confirming the indissociability between the State and the economy within the paradigm of liberty, we still need to reach a conclusion with regard to the level and the type of insertion that the State should have as a provider of social rights. This subject, which is the logical sequence of the present argument, will be discussed next.

\section{StATE AND MARKET: Two SidES AND JUST ONE COIN}

Bresser-Pereira (2009) defines the state as a constitutional/legal system and the organization that guarantees it, and, therefore, the fundamental institution of each society, being the source of the other institutions and the coordination or regulation principle, having power over all society and the political apparel that executes and reforms it. The market, on the other hand, is defined by this author as a 
mechanism for economic competition regulated by the state that enacts a relatively automatic regulation of economic action. It is the institution that complements the much broader coordination of the state (B resser-Pereira, 2009, 2010).

Hobbes and Locke are the fathers of the discussion concerning the size and nature of the power that the State should exert over the liberties of citizens. B oth are contractualists - a line of thought that believes that human society is formed through a form of social contract in which each individual gives up part of his power of choice to a higher power, embodied in the form of State (Chevallier, 1982; M elo, 2006; Ribeiro, 2006). The portion of power that will be given up by each individual relates directly to the form the State will assume, which, in turn, is closely related to the needs it will meet.

Therefore, Hobbes and Locke start from the State of Nature - but for Hobbes this is more human nature than a form of pre-social state, as can sometimes be illustrated. It is this human nature, or what we should expect from others, that will determine the need for authority of the State. For Hobbes, $\mathbf{M}$ an is a wolf to Man, man is his own worst predator. This pessimist view of human nature leads him to the conclusion that all individual power should be given up to the State, and that it should be the beholder of all social choices, while also being above all laws created in order to protect man from man himself (Chevallier, 1982; M elo, 2006; Ribeiro, 2006).

For L ocke, however, a man in the State of Nature (in this case, more pragmatic than Hobbes, the State of $N$ ature reflects, in fact, a pre-social, pre-politic human association) is free, equal and independent since everyone is subjected to the laws of Nature, laws that re-assert themselves on the frontier of individual liberties. In this way, by not paying respect to individual liberties, an individual gives others the right to punish him, this being the cause of wars. It is no longer a war of every man against every man, as Hobbes theorized, but rather a war of the followers of the laws of nature against the transgressors of such laws. This premise corresponds to a State, the sole objective of which is to provide liberty, equality, justice and the right to property. This is the origin of Liberalism (Chevallier, 1982; M elo, 2006; Ribeiro, 2006).

A ccording to Nogueira and M essari (2005), Liberalism, also called Idealism, stems from L ocke's ideas and, based on A dam Smith, it builds an ideal world project, in which the exchanges (the market system), through the effects of spill over, will, in turn, subsidize improved quality of life for all members of a liberal society. A martya Sen (2001) quotes A dam Smith's passage about the butcher, the brewer, and the baker's motivation, which, regardless of being self-interested, end up producing the common good. This part is symbolic, indicating how a liberal society plans for itself to encompass a well accepted integration of what Hayek (1973) would call spontaneous order. This order, which stems from exchange, has also been geared in the idea that everything can be exchanged - bought and sold.

Nevertheless, Sen (2001) argues that there are dimensions in which the market fails, or there are goods that cannot be individually bought, such as social well being. In order to maintain an adequate living environment, to overcome an epidemic or for social development to exist, the costs should be dealt with collectively. In this way, the market's individualist rationality would only be applied to private goods. However, there would also be mixed goods such as Education and Health. Sen (2001) calls them mixed because although they are advantageous from the point of view of the individual, which would lead him to wish to acquire them in the market, they are also too important to the community to be left at the mercy of the market. These services that contribute directly to the quality of life end up being turned into social rights because they generate an increase in quality and in the population's life expectancy even when other levels of development (such as income level, for example) have not yet been reached.

After World War II, the new authorities responsible for the reconstruction of Europe identified the need to make many concessions to the population. Capital importance was given to planning, as a way of avoiding a return of the factors that emerged in the period between the two world wars, which were determinant to the emergence of authoritarian governments (fall of stock market, unemployment, inequalities, etc). Therefore, for democracy to work and recover its appeal, it would need to be planned. In this way, the State would have to intervene in the economic environment in order to avoid situations of imbalance, inefficiency, inequality and injustice. The new governments, who would lead preventive 
States, represented the hope that an individual would be protected from falling into misery, even if it meant high financial costs assumed by the State (J udt, 2008).

Esping-A ndersen (1996) argues that this Welfare State has been in decline ever since it became incompatible with other objectives of economic development. The crisis of the Welfare State has both intrinsic and extrinsic elements - failure of the market and failure of the Welfare State itself - since it was not able to update itself when faced with the new global social economic configuration at the end of the 20th century. Thus, the new world order proclaimed that the path to growth and prosperity was paved with flexibility and deregulation.

A nother point of friction between market and State is the protectionist measures that the States can assume with regard to its own economies in relation to the international market. In "Embedded Autonomy - States and Industrial Transformation" Peter Evans (1995, pp. 3-20) analyzes the protectionist policies of some emergent countries in the international economy. Describing the international environment under the Division of Labor perspective, the author identifies these protectionist measures as a way to establish a favorable environment for the development of the local industry, at a later time allowing that nation to adhere to the international division of labor in more favorable terms. The basis of his argument is that strengthening the national industry is only possible when it is not exposed to competition from developed economies. It is this favored development that would later make domestic industry more apt to compete in the international market environment. In this and many other ways, interventionism generates a national autonomy that is more deeply rooted or more substantial, which implies stronger connections to industrial capital (Evans, 1989, 1995).

According to Bresser-Pereira (2009), the neoclassic economic theory, the new institutionalism, the theory of public choice and the theory of rational choice are at the core of the theoretical assault perpetrated against the state (Bresser-Pereira, 2009; Evans, 1989). The neoliberal movement, which stems from Hayek's thinking, is constructed from the argument that puts the State at an enormous disadvantage when compared to the $M$ arket, turning it into a machine that is not only inefficient and inept, but also useless and criminal (Bresser-Pereira, 2009; Evans, 1989, 1997). In this sense, Evans (1997) argues that the danger is not that the State ends up as a marginal institution, but that more limited and repressive forms are accepted as the only way to avoid the collapse of public institutions (Evans, 1997).

A country that is developed in the economic, social and political fields is a country whose nation has in its service a strong and capable State, regulating a free and efficient market. Therefore, state and market are institutions of society - they are its instruments of collective action, the main tools for each society to achieve its objectives and, as such, they are complementary rather than alternative (Bresser-Pereira, 2009).

B eyond the fundamental regulating role of the state, it can al so be protective, inductive, a capacitator and, in the early stages of economic development, it can also be a producer (Bresser-Pereira, 2009). Studying the creation and the impact of state-owned companies in Brazil, Rodrigues (1990) identified, for example, that the creation of state-owned companies (and the investments made in such companies) in B razil was responsible for promoting a radical change in the country's productive structure and created infrastructure and base industry that made the industrialization process that occurred between 1965 and 1980 possible, i.e., that state-owned companies play a complementary role to that of private companies (Rodrigues, 1990).

\section{DEMOCRACY, LIBERTY AND CIVIL RIGHTS}

Civil society encompasses all forms of social relations that do not fall within the margin of the state, but neither do they have any sort of influence over it. It is constituted by the people, but while the people is the array of citizens that are considered equal under the law, the political power that each citizen 
possesses in civil society is extremely variable (Bresser-Pereira, 1995; Grin, 2009). In modern democracies, the power of the state derives, in theory, from the people, but this is only true when the civil society itself is democratic, i.e., when it is increasingly identified with the people (B resser-Pereira, 1995).

As society becomes more democratic, civil society increases its base and begins to include the middle class and, eventually, the workers. The closer civil society and the people are, the more egalitarian are the citizens' political rights, the more democratic will the civil society be (B resser-Pereira, 1995).

According to Grin (2009), understanding the relation between civil rights and democracy in B razil is of fundamental importance for the construction of effective citizenship. Despite the apparent contradiction between individual liberties and the reinforcement of the state - especially if one considers the classical liberal thinking - in countries such as Brazil, where the political process was historically conducted to respond only to the interests of dominant oligarchies, not seldom do we observe that it is the state that comes forth to defend, reassure and - more often than not - implement an agenda of civil rights.

Historically, since the dawn of the Republic, and up to the 1930's, in the so called Old Republic period, the creation of a representative regime and the formalization of political rights occurred before the implementation of effective civil liberties. In the Era of the Colonels, the federative regime served mostly as a way to disguise the defense of oligarchic interests. In a rather curious paradox, civil rights were sacrificed in the name of political rights, especially when it came to access to justice and other public institutions, put to the service of private and patrimonialistic interests (G rin, 2009).

It was only in the 1930's, in the Vargas' Era, a period marked by the rise of authoritarianism and the decisive presence of the State in the economy, that an agenda of civil rights began to evolve, contemplating the establishment of labor unions, female suffrage, minimum wage and several other social and political reforms consolidated in the 1934 and 1937 Constitutions. Throughout the following decades, Brazil would experience alternating periods of liberalization and statization, just as it would experience alternating periods of democratic and authoritarian regimes, culminating with the 1964 military coup that subjected the country to roughly 20 years of dictatorship (Grin, 2009).

However, since the mid 1980 's, in the scope of the re-democratization process, after more than 20 years of a military regime, Brazil has experienced new forms of social and political participation, which had their natural development in the search to strengthen an organized civil society, especially after the state reforms of the 1990's (Souza, 1992).

\section{THE Evolution OF THE BRAZILIAN STATE}

Throughout its history and successive governments, B razil has had the goal of transforming itself into a modern, independent, industrialized nation capable of playing a relevant role on the international scene. Development being the greatest national goal, the internal discussions and disputes have always been between "nationalism, state models and the market ideologies of a classical economy" (Peixoto, 2008, p. 7), since the State is al ways seen as "the main institution for the tasks of planning, coordination and the country's supply of development" (Peixoto, 2008, p. 7). This is the orientation towards modernization and susceptibility to the international environment that would guide the changes throughout the 20th century.

Created and supported in an economy that was predominantly commodities-exporter, based in the coffee culture, the B razilian Republican State lived its first decades at the mercy of the interests of the most influential local oligarchies'. The promulgation of the Constitution in 1889, a federalist constitution, set the State as the guardian of public order, defining a State of Liberal Right and starting the debate over the decentralization of political power (Di Pietro, 2006, Selcher, 1990; Souza, 1992). From the economy to foreign policy, the B razilian State seemed to exist solely to comply with the 
interests of the coffee planters of São Paulo State. According to Matias-Pereira (2008), "the oligarchical State in the period identified as the Old Republic or of the Colonels (1889-1930), gave little importance to the public policies of a social character or the mobilization of civil society" (p. 90).

It was only with the onset of the 1929 world crisis, when "the historical conditions that brought about the fall of the oligarchical regime" (Matias-Pereira, 2008, p. 90) appeared, that this picture began to change. G etúlio Vargas' rise to power through the 1930 R evolution heralded the beginning of the implementation of a different model of State in the midst of Brazil's industrialization process: the Social State of the Right (Di Pietro, 2006; Selcher, 1990).

In the so called V argas era, the State began to play a determinant role, intervening heavily in the productive sector, providing goods and services. The Public Administration was submerged into a "strong process of rationalization" (Matias-Pereira, 2008, p. 89) and the "implementation of a model of bureaucratic administration" (M atias-Pereira, 2008, p. 89) directly related to the modernization of Brazil's existing capital system started with a strong drive for centralization. In this context, we see public bureaucracy allied with the industrial bourgeoisie and no longer the former patrimonialist bureaucracy of the oligarchical regime (Almeida, 2004; Bresser-Pereira, 2007; Di Pietro, 2006; M atias-Pereira, 2008; Selcher, 1990).

According to the Fordist societies of the time, $V$ argas' government initiated a process of establishing the national institutional foundations, which included labor rights, public education, universal suffrage and a new Constitution. In attempting to develop a W elfare State in B razil, V argas also created great public institutions that would mediate the relationship between State and Society and also contributed to the collective organization of the working class through unions and sectional organizations. The State saw a growing increase in public administration and bureaucracy due to the instatement of public services, including Health and Education (Di Pietro, 2006; M atias-Pereira, 2008; Souza, 1992).

The Brazilian State recognizes itself as the driving force behind the economic activity, impinging heavily on industrial sectors, especially base industries, the most eloquent example being the creation of the National Steel-industry Company [CSN ] in V olta Redonda located between Rio de Janeiro and São Paulo (M atias-Pereira, 2008; Rodrigues, 1990).

W ith the advent of authoritarian regimes (such as the Nazi regime in Germany and Fascism in Italy), $V$ argas' regime was also hardened politically, and the period of the New State was born (MatiasPereira, 2008; Selcher, 1990), in which political tendencies such as "clientelist and populist that were traces of the ideology of an authoritarian Getúlio V argas government" were intensified (M atiasPereira, 2008 p. 90). At this point a growing insertion of the State in the economy and social services was observed (M atias-Pereira, 2008; Selcher, 1990)

With the end of World War II and the fall of the authoritarian regimes, Brazil also experienced its time of redemocratization, accompanied by a more liberalizing orientation of governmental action. The economic debate at that time was polarized between the adepts of an orthodox administration of the economy and those who defended state planning, closely identified with the so-called developmentalists, and this contributed to a certain discontinuance in government action, and even to the overlapping of contradictory measures in terms of macroeconomic and sectorial policies (A Imeida, 2004).

However, with Vargas' return to power, and especially with the subsequent election of Juscelino K ubitschek in 1955 (one year after Getúlio's suicide), the developmentalist project was back in vogue. At first, this project was marked by Getúlio V argas' strong nationalism, exemplified by the 'The Oil is ours!' campaign that culminated in the creation of Petrobrás and the establishment of a state-owned monopoly for the exploration and production of oil in Brazil. With JK's election, the Brazilian State went through another re-orientation, supporting an economic development that placed great emphasis on the stimulation of industrial activity (especially the automobile industry) and civil construction, the construction of the country's new capital, Brasilia, being its most expressive achievement (Almeida, 2004). 
Even though Esping-Andersen (1996) is right when he argues that the Welfare State became incompatible with other objectives for development, the authoritarian and positivist rationality of the Welfare State (known in Brazil as the Social State of Right, and which Hayek would call Taxis) was responsible for social innovation in many aspects. During the Vargas Era, Brazil witnessed the emergence of a great deal of regulatory laws; and even though they were accused of being populist and antidemocratic, they changed society's feelings of entitlement. Great social advances were made from decisions that could be traced to authoritarian roots. It is hard to believe that based solely on market mechanisms and mutual adaptation it would be possible to reach such a level of social right sophistication as was seen in V argas' $N$ ew State. A nd this feeling of entitlement persisted even after the fall of the authoritarian regime. As Charles Lindblom (1980) argues, progresses and intelligent decisions can be made when we temporarily give up some traits of democracy.

In fact, it can be argued that from this feeling of entitlement, once the basic social needs are met, the demand for more abstract concepts, such as liberty, can arise.

Nevertheless, another change in the political panorama would alter the form and organization of the B razilian State. The democracy experienced by the country through the second half of the 1950s and early 1960 s ended abruptly with the military coup of $M$ arch, $31^{\text {st }}, 1964$. Establishing a "new period of exception that had negative effects on the Brazilian civil society" (M atias-Pereira, 2008, p. 91), the military regime led to increased intervention of the State in civilian matters, the State being viewed once again as the driving force behind the economy, investing heavily in infrastructures (roads, urbanization, telecommunications and energy generation), supporting the installation of large transnational companies in the country and the modernization of several sectors of the economy (M atias-Pereira, 2008; Peixoto, 2008; Selcher, 1990). Furthermore, principles of administrative rationality in State actions such as budgeting, planning and goal establishment were also instituted (M atias-Pereira, 2008). The basis for the State's action during the military period was a nationalist social ideology of a developmental nature - bureaucratic, a provider and authoritarian (Peixoto, 2008).

An example of this can be seen in the 1968-1970 Strategic Development Plan. This document consisted of economic policy and sectorial directives, with some directions for regional development. Despite not being hostile to direct foreign investments in the Brazilian productive sector, the SDP (PED, in Portuguese) focused on the necessity of the state's participation to bridge the gaps in the economy so as not to allow the consolidation of foreign capital in areas that were strategic for development (A Imeida, 2004).

The Goals and B ases for the Government A ction Program (1970 as cited in A Imeida, 2004) foresaw that $B$ razil would enter the developed world by the turn of the century, defining four primary areas: (a) education, health and sanitation; (b) agriculture and supply; (c) scientific and technological development; (d) the strengthening of the competitive power of domestic industry. The first National Development Plan (1972-1974) sought to implement great national integration projects (transport and communications) and officialized the concept of a Brazilian model, while the second one (19741979) was dedicated to investments in base industries (steel and petrochemicals). Thus, the intention was to achieve autonomy in basic inputs, but it began within the context of the energy crisis (Almeida, 2004).

During the military regime, and initially seen as a form of political and social resistance, the appearance of important social and labor movements would later lay the foundations for the redemocratization movement and help the constitution of a Brazilian civil society that, according to M atias-Pereira (2008), would be much more structured. In other words, from the midst of socializing, authoritarian politics sprouted the seeds of demand and the pursuit of liberty. Social inclusion, basic rights and an increase in the power of choice generated a great number of well fed, healthy and educated citizens, who ended up questioning the legitimacy of the regime.

In the re-democratization scenario, in 1988, a new Federal Constitution was proclaimed which, in its preamble, defined the Brazilian State as a State of Democratic Rights (Di Pietro, 2006). 
In the midst of the economic crisis, marked by hyperinflation and the growth of the country's foreign debt, the movement for redemocratization and the New Republic were faced with serious questions regarding the size and efficiency of the state. In light of the 1988 Constitution, which very strictly regulated the action and function of Public Administration, Collor's government proposed to reduce the number of employees in the government's administration. The neo-liberalization ideals were evident when he began to privatize some government-owned sectors such as steel, petrochemicals and utilities. The lowering of trade barriers al so rapidly exposed B razilian firms to fierce competition from abroad (A mann \& B aer, 2008). However, since it was not carried out in a proper fashion, the reform of the public sector and the weakening of the government's role only aggravated the existing problems, leading inflation to spiral out of control again (Peixoto, 2008).

Following Collor's impeachment, V .P. Itamar Franco took office and initiated a process of profound reforms, starting with the economy and extending to the reform of the Brazilian State. This was followed by the two terms of Fernando Henrique Cardoso (1994-1998 and 1999-2002) (Peixoto, 2008).

Due to globalization and changes in the international system since the fall of the Berlin W all and the end of the Cold War, the State's reform and the modernization of the public sector once again came back into focus as key-points in the government agendas (Peixoto, 2008). The reform of the public sector was seen as a road to achieving efficiency and modernization. In this scenario of internal and external political disputes, many countries find themselves confronted with the need to "determine the responsibilities of the state and the limitations of its actions" (Peixoto, 2008, p. 6).

Regardless of the ideology or political affiliation of the rulers, in the last two decades, the reforms of the Brazilian state have been dedicated to the "change of the managerial bureaucratic model from the provider State to the regulator State" (p. 13), or in the words of Peixoto:

the developmental, intervener and developmental State, molded by Keynesianism, gave way to a proposal for a rational State model that is less interventionist, more committed to economic stability and fiscal adjustments than with spectacular rates of economic growth, and is tuned with monetarism and fiscal authority (p. 13).

However, despite being directed towards an economic liberalism that was strongly present in the Constitution of 1988, the Brazilian State did not give up maintaining a socializing and inclusive character with the innovation of promoting a vision of development associated with sustainability and putting the protection of the environment as a citizen's right and the State's responsibility. As such, B resser-Pereira (2007) presents the historical forms and administrations of the State, shown in the table below:

Table 1

H istorical F orms of State and A dministration

\begin{tabular}{llll}
\hline Category & $1821-1930$ & 1930- 1985 & 1990 \\
\hline State/Society & Patriarchal & National & Liberal \\
& dependent & developmentalist & dependent \\
Political Regime & Oligarchical & Authoritarian & Democratic \\
Managerial Class & $\begin{array}{l}\text { Latifundiaries and } \\
\text { patrimonial bureaucracy }\end{array}$ & $\begin{array}{l}\text { Public Bureaucracy and } \\
\text { industrial bourgeoisie } \\
\text { (executives) }\end{array}$ & $\begin{array}{l}\text { Financial A gents and } \\
\text { Financial Investors }\end{array}$ \\
Administration & Patrimonial & Bureaucratic & M anagerial \\
\hline
\end{tabular}

Note. Source: B resser-Pereira, L. C. (2007). Burocracia pública e classes dirigentes no Brasil (p. 11). Revista de Sociologia, (28), 0-30. 


\section{COMPARATIVE ANALYSIS}

Observing the evolution of the Brazilian State, we can construct a comparative chart in which the forms of State can be analyzed according to the following dimensions:

. Individual liberty, inspired on Hayek's concept;

. Socializing character, which is important to guaranteeing equity, and

- Predominance in relations to the State/M arket dichotomy.

Table 2

F orms of G overnment after the Proclamation of the R epublic

\begin{tabular}{llll}
\hline Forms of Government & Individual Liberties & Socializing Character & $\begin{array}{l}\text { State/M arket } \\
\text { Predominance }\end{array}$ \\
\hline Old Republic & High & Low & M arket \\
Vargas' Era & Low & High & State \\
Redemocratization & High & Low & State \\
Military Government & Low & High & State \\
New Republic & High & High & M arket \\
\hline
\end{tabular}

Note. Source: Developed by the authors

This comparative table allows one to visualize a new paradigm of the B razilian State's configuration, according to the studied dimensions. A fter consecutive periods of State predominance, we resume the perspective of $M$ arket as a bias of governance. In parallel, individual liberties and the socializing character appear with high relevance, simultaneously, for the first time since the Old Republic.

This new configuration of the State is unheard of in Brazil's recent history. It surely introduces the perspective of imminent change in all relations that involve public administration at the three levels of government, and it deserves the attention of experts in the field.

There are many possibilities of significant changes in the various aspects of public administration actions, ranging from public policies and government formulation to the evaluation of social promotion programs, not to mention the perspective of altering the dynamics of governance that would certainly impose new limitations on the traditionally bureaucratic environment of the public sphere.

Faced with this new configuration, it is necessary to bear in mind the need for discussion and debate of a new approach to emerging questions. A mong the most relevant aspects to be taken into consideration in this new view of the Res Publica, the "public thing", it is absolutely imperative to propose new methodologies for analyzing the observational reality of the public sector and discuss the new theoretical approaches that allows us to understand the organizational phenomena which we will have to face from now on more clearly.

The new dynamics of the Brazilian State lack a synchronized mapping. M ore specifically, this is the time for reflection, debate and academic propositions that could set us in tune with the new Brazilian reality. 


\section{FinAL CONSIDERATIONS}

The evolution of government models adopted throughout the 20th century in Brazil evidently shows that certain moments of economic development in the country require protectionist measures, such as market reserve. The rationale behind this is to create ideal conditions for industry to blossom and prepare for the overseas market. At other times, it may be necessary to be more flexible when it comes to tariffs in order to attract international capital and investments.

It is necessary to remember that some social advancements can only be achieved if they are not subjected to market consensus. These social advancements, which in Brazil are incorporated as a system of universal Health and Education, as citizens' basic rights, labor rights, and others, are the fundamental elements of equity that will in fact guarantee liberty of choice and not merely serve as rhetoric of liberty, even though B razil is still far from an ideal of equity, and arbitrariness still operates on many fronts.

The dialectical nature of the power of the State and $M$ arket being characterized by the fight for legitimacy in the organization of society leads us to believe in the non precedence of one over the other, and that both are equally important, having complementary objectives, the market's objective being to generate economic value and the State's being to generate social value, both helping to increase individual liberties and the common good.

Thus, we come to the conclusion that the focus should not be the maximum or minimum State, but rather the dynamic State in which many variable dichotomies will influence the pressure of the international environment versus the State of economic development, the social guarantees versus the demand for individual liberties. Due to this dialectical character, it can be argued that the State's level of intervention and regulation in the economy and in social welfare is contingent and will always be subject to the intemperance of the economy and politics, aside from the pressures from civil society (both national and international). This contingencial approach to the size of the State involves and requires a country's political body to be highly flexible and capable to adapt; and from the market, greater tolerance and a long term view are required.

This study can be said to have achieved its proposed objective of analyzing the evolution of the B razilian governmental organization and identifying the assumptions behind the various reforms that took place after the proclamation of the Republic, taking into account the dimensions of development and liberty in relation to the State/M arket dichotomy. However, none of the discussed dimensions in this study have been exhausted. The optimum size for the State is far from being clearly defined and the interaction between State and market is a fertile field for political, academic or ideological debate, and also for theoretical, qualitative or quantitative studies that do not exhaust themselves in only a few pages. This constitutes the main limitation of this work. The analysis of the participation of civil society has been brief and many issues remain to be discussed that could not be included here, this being another limitation of the study.

\section{REFERENCES}

Almeida, P. R. (2004). Planejamento no Brasil: memória histórica. Brasília. Parcerias estratégicas, (18), 157-190.

A mann, E., \& Baer, W . (2008). Neo-liberalism and market concentration in B razil: the emergence of a contradiction? The Quarterly Review of E conomics and Finance, 48(2), 252-262.

Blanc, M . (1994). Os herdeiros de D arwin. São Paulo: Página A berta. 
B resser-Pereira, L. C. (1995). Estado, sociedade civil e legitimidade democrática. Lua Nova Revista de Cultura e Política, (36), 85-104.

Bresser-Pereira, L. C. (2007). Burocracia pública e classes dirigentes no Brasil. Revista de Sociologia, (28), $0-30$.

B resser-Pereira, L. C. (2009). A ssalto ao Estado e ao mercado, neoliberalismo e teoria econômica. Estudos avançados, 23(66), 7-23.

Bresser-Pereira, L. C. (2010). Democracia, estado social e reforma gerencial. Revista de Administração de Empresas, 50(1), 112-116.

Cerny, P. G. (2008). Embedding neoliberalism: the evolution of a hegemonic paradigm. The J ournal of International Trade and Diplomacy, 2(1), 1-46.

Chevallier, J.-J . (1982). As grandes obras políticas de M aquiavel a nossos dias. B rasília. U niversidade de Brasília.

Colander, D. (2005). The many roads to serfdom. European Journal of Political Economy, 21(4), 1060-1063.

Datz, G. (2009). State of change: global turmoil and government reinvention. Public Administration Review, 69(4), 660-667.

Di Pietro, M. S. Z. (2006). 500 anos de direito administrativo brasileiro. Revista Eletrônica de Direito do Estado, (5), 1-25. Retrieved A ugust 26, 2008, from http://www.direitodoestado.com/revista/REDE-5-J A NEIRO-2006-

MARIA\%20SY LVIA\%20ZANELLA.pdf

Esping-A ndersen G. (1996). Welfare States in transition: national adaptations in global economies. Londres: Sage Publications.

Evans, P. B. (1989). Predatory, developmental, and other apparatuses: a comparative political economy perspective on third world states. Sociological Forum, 4(4), 561-587.

Evans, P. B. (1995). E mbedded Autonomy. N ew Jersey: Princeton U niversity Press.

Evans, P. B. (1997). The eclipse of the state? Reflections on stateness in an era of globalization. World Politics, 50(1), 62-87.

Gore, C. (2000). The rise and fall of the washington consensus as a paradigm for developing countries. World D evelopment, 28(5), 789-804.

Grin, E. J. (2009). Democracia e direitos civis no Brasil:um debate necessário. Revista Videre, 1(1), 65-86.

Hayek, F. A . (1973). Law, legislation and liberty. Chicago: University of Chicago.

Judt, T. (2008). Pós-guerra: uma história da Europa desde 1945. Rio de J aneiro: Objetiva.

Lindblom, C. (1980). 0 processo de decisão política. Brasília: Universidade de Brasília.

Matias-Pereira, J. (2008). Curso de administração pública, foco nas instituições e ações governamentais. São Paulo: A tlas.

M elo, L. I. A . (2006). J ohn L ocke e o individualismo liberal. In F. C. W effort (Org.), Os clássicos da política (pp. 79-110). São Paulo: Ática.

Nogueira, J. P., \& M essari, N . (2005). Teoria das relações internacionais. Rio de J aneiro. Elsevier. 
Peixoto, J. P. M. (2008). Statecraft no Brasil: ideologia e pragmatismo. In J. P. M. Peixoto (Org.), Governando o governo modernização da administração pública no Brasil (pp. 1-29). São Paulo: A tlas.

Ribeiro, R. (2006). Hobbes: o medo e a esperança. In F. C. W efort (Org.), Os clássicos da política (pp. 51-77). São Paulo. Ática.

Rodrigues, P. H. (1990). A campanha "antiestatização" e o desempenho das principais empresas estatais (1965-85). Revista de Administração Publica, 24(1), 44-73.

Santos, R. S., Ribeiro, E. M., Gomes, C., Santos, L. C., Caribe, D. A., Souto, I. M . I., \& Silva, C. D., J r. (2007). Compreendendo a natureza das políticas públicas do estado capitalista. Revista de Administração Publica, 41(5), 819-834.

Selcher, W . A . (1990). 0 futuro do federal ismo na nova república. Revista de Administração Publica, 24(1), 165-190.

Sen, A . (2001). D esenvolvimento como liberdade. São Paulo: Companhia das Letras.

Sheppard, E., \& Leitner, H. (2010). Quo vadis neoliberalism? The remaking of global capitalist governance after the washington consensus. G eoforum, 41(2), 185-194.

Souza, C. M. (1992). Democracia participação social e funcionamento das instituições: situação e perspectivas da federalização do desenvolvimento. Revista de Administração Publica, 26(3), $15-35$.

Williamson, J. (1990). What Washington means by policy reform. In J. Williamson (Ed.), Latin American Adjustment: how much has happened (pp. 5-20). Washington, DC: Institute of International Economics.

Williamson, J. (1993). Democracy and the 'W ashington Consensus'. World Development, 21(8), 13291336.

Williamson, J. (1997). The W ashington consensus revisited. In L. Emmerij (Ed.), Economic and social development into the XXI century (pp. 48-61). W ashington, DC: Inter-A merican Development Bank. 